\title{
Performance of Twelve Corn Hybrids and Selections in Three Consecutive Crops on the Same Site in the Same Year
}

\author{
A. Sotomayor-Rios ${ }^{2}$
}

\begin{abstract}
Twelve corn (Zea mays L.) hybrids and selections were planted three times on the same site in the same year at Isabela, Puerto Rico, according to the following schedule: Nov. 5, 1975 (crop 1); April 21, 1976 (crop 2); and Aug. 13, 1976 (crop 3). Average time to midsilk for the 12 entries was similar in crops 1 and 3 (62.1 and 61.6 days, respectively) but was shorter in crop 2 (59.1 days). Average height to the base of the lowest ear for the 12 entries was $87.1,106.3$, and 99.0 $\mathrm{cm}$ for crops 1,2 , and 3 , respectively. Average test weight was highest $(81.2$ $\mathrm{kg} / \mathrm{hl}$ ) in crop 1, decreasing to 72.4 and $55.0 \mathrm{~kg} / \mathrm{hl}$ in crops 2 and 3 , respectively. Average severity of leaf blight, caused by Bipolaris maydis (Nisikado) Shoemaker, was similar in crops 1 and 2 . The best grain yielder in all three crops was hybrid Pioneer $304 \mathrm{C}$, with yields of $5,975,4,103$, and $3,729 \mathrm{~kg} / \mathrm{ha}$ in crops 1,2 , and 3 , respectively. The average yield for the 12 entries was $4,598,3,180$, and $2,523 \mathrm{~kg} / \mathrm{ha}$ in crops 1,2 , and 3 , respectively.

Nematodes in plots were counted and identified after crop 3 was harvested. The nematode most commonly found in the rhizosphere was Pratylenchus zeae. Plots with Pioneer $304 \mathrm{C}$, the top yielder, had the second lowest nematode count, 480 per $250 \mathrm{~cm}^{3}$ of soil. Plots with PR-3 and the $\mathrm{F}_{1}$ hybrid $\mathrm{PRMO}_{2} \times \mathrm{PR}-3$ had the highest nematode counts, 1040 and 1232 per $250 \mathrm{~cm}^{3}$ of soil, respectively. Although soil disinfestation might have resulted in higher yields, this study showed that three corn crops grown on the same site during the same year can produce grain yields of more than $13,000 \mathrm{~kg} / \mathrm{ha}$ (205 bu/acre).
\end{abstract}

\section{INTRODUCTION}

Corn is an important component of animal feed in Puerto Rico, but most is imported. Imports of corn and corn products during 1975-76 were valued at more than $\$ 33$ million. If level land suitable for mechanization and irrigation were available, the production of corn in Puerto Rico would have a considerable economic potential.

Recent research indicates that with adequate management, excellent corn yields can be obtained in Puerto Rico. Talleyrand et al. (10) obtained a yield of 8.4 tons/ha (134 bu/acre) with Funk's G-795W on an Humatas soil fertilized with $\mathrm{N}$ at $200 \mathrm{~kg} / \mathrm{ha}$. They attributed a lower yield (only 5.4 tons/ha) with Funk's G-795W on a Bayamón clay to late planting and a moderate attack of leaf blight. Fox et al. (7) reported a maximum yield of about 6.3 tons/ha from hybrid Pioneer 306 during 1970-72.

Webster and Walker (11) tested 18 corn cultivars at Mayagüez, Puerto Rico, for resistance to earworm, Heliothis zea (Boddie); sugarcane borer, Diatraea saccharalis (Fabricius); corn silk maggot, Euxesta stigmatias

\footnotetext{
' Manuscript submitted to Editorial Board May 9, 1978.

${ }^{2}$ Research Geneticist, USDA, Science and Education Administration, Mayagüez Institute of Tropical Agriculture, Mayagüez, P. R. 00708.
} 
Loew; corn rust, caused by Puccinia polysora (Underw.); and corn leaf blight, caused by Bipolaris maydis (Nisikado) Shoemaker. They found significant differences in severity of pest infestation between sprayed and unsprayed plots, and they stressed the importance of controlling the armyworm, Spodoptera ornithogalli (Guenée) in seedlings for successful corn production in Puerto Rico.

This study was conducted to evaluate the yield potential and to measure selected characters of 12 corn hybrids and selections in three consecutive crops at the same site during the same year.

\section{MATERIALS AND METHODS}

The corn hybrids and selections tested were obtained in 1975 from commercial suppliers and from seedstock of the Mayaguez Institute of Tropical Agriculture (MITA), Mayaguez, Puerto Rico. Kernel types varied from small to large and from white and yellow to dent and flint. The 12 entries included six commercial hybrids-Pioneer 105A, 304B, 304C, and 306B, and DeKalb B-660 and B-666; four samples of populations with broad genetic bases, potential sources of resistance to rust and blight-PR-Mp4 (4), PRMo2 (5), PR-3 (release pending), and PR-Mo2 $\times$ PR-3; and two well-adapted local varieties-Mayorbela and Diente de Caballo.

All 12 entries were planted on the same site three times in the same year, according to the following schedule: November 5, 1975, first planting; April 21, 1976, second planting; and August 13, 1976, third planting. The three plantings were at the Isabela experiment farm of the MITA, in northwestern Puerto Rico. The farm is $128 \mathrm{~m}$ above sea level and the temperature ranges from $18^{\circ}$ to $31^{\circ} \mathrm{C}$. The soil is a Coto clay (an Oxisol), pH 5.0 to 5.5. Before each planting, a complete fertilizer (15-5-10) was applied to all plots at about $560 \mathrm{~kg} / \mathrm{ha}$. For control of soil nematodes and insects, carbofuran ${ }^{3}$ (2,3-dihydro-2,2-dimethyl-7-benzofuranyl methylcarbamate) was band applied with the fertilizer at about $6 \mathrm{~kg} / \mathrm{h}$ a to all rows. Immediately after planting, propazine [2-chloro-4,6-bis(isopropylamino)$s$-triazine] was applied to all plots at 2 to $3 \mathrm{~kg}$ of active ingredient per hectare. Methomyl (S-methyl $N$-[(methylcarbamoyl)oxy]thioacetimidate) was sprayed at $0.27 \mathrm{~kg}$ of active ingredient per hectare every 10 to 14 days to control insects.

A randomized block design with five replications was used for each experiment. Each plot included four rows spaced $101 \mathrm{~cm}$ apart and about $6 \mathrm{~m}$ long. Plants were spaced about $25 \mathrm{~cm}$ apart in the rows. A $4-\mathrm{m}^{2}$ area

\footnotetext{
${ }^{3}$ Trade names are used in this publication solely for the purpose of providing specific information. Mention of a trade name does not constitute a guarantee or warranty of equipment or materials by the Agricultural Experiment Station of the University of Puerto Rico or an endorsement over other equipment or materials not mentioned.
} 
from the two inner rows of each plot was used for grain-yield sampling. The samplings were made on March 8, 1976; July 27, 1976; and November 29, 1976, for the first, second and third crops, respectively. Ears were harvested and dried to a uniform moisture content before shelling. Yields of shelled grain were adjusted to $15.5 \%$ moisture. In addition to yield, data were collected on time to midsilk, height to the base of the lowest ear (measured on four plants/plot), and test weight. In the first two plantings, leaf blight severity by row was evaluated on a scale of 0 (no lesions) to 4 (75 to $100 \%$ of leaf area covered with lesions). Data were subjected to analysis of variance, and significant differences were identified with Duncan's multiple range test.

TABLE 1.-Yield and other characters of 12 corn entries planted on November 5, 1975, at Isabela, P. R.'

\begin{tabular}{lccccc}
\hline \multicolumn{1}{c}{ Entry } & $\begin{array}{c}\text { Time } \\
\text { to } \\
\text { midsilk }\end{array}$ & $\begin{array}{c}\text { Height } \\
\text { to } \\
\text { lowest } \\
\text { ear }\end{array}$ & $\begin{array}{c}\text { Test } \\
\text { weight }\end{array}$ & $\begin{array}{c}\text { Leaf } \\
\text { blight } \\
\text { rating }\end{array}$ & Yield \\
\hline Pioneer 304C & $\begin{array}{c}\text { Days } \\
60.4 \mathrm{e}\end{array}$ & $\begin{array}{c}\mathrm{Cm} \\
78.0 \mathrm{e}\end{array}$ & $\begin{array}{c}\mathrm{Kg} / \mathrm{hl} \\
82.0 \mathrm{bc}\end{array}$ & $1.4 \mathrm{~h}$ & $5975 \mathrm{a}$ \\
Pioneer 306B & $64.8 \mathrm{~cd}$ & $93.0 \mathrm{bc}$ & $80.6 \mathrm{~cd}$ & $1.6 \mathrm{fgh}$ & $5734 \mathrm{a}$ \\
Pioneer 105A & $64.6 \mathrm{~cd}$ & $80.6 \mathrm{cde}$ & $82.0 \mathrm{bc}$ & $1.7 \mathrm{efgh}$ & $5593 \mathrm{a}$ \\
DeKalb B-666 & $67.4 \mathrm{ab}$ & $100.7 \mathrm{ab}$ & $81.8 \mathrm{bc}$ & $2.0 \mathrm{cdef}$ & $5331 \mathrm{a}$ \\
Diente de Caballo & $62.8 \mathrm{~d}$ & $92.3 \mathrm{bcd}$ & $79.0 \mathrm{ef}$ & $1.8 \mathrm{efgh}$ & $5223 \mathrm{a}$ \\
PR-Mp4 & $63.6 \mathrm{~d}$ & $84.2 \mathrm{cde}$ & $80.6 \mathrm{~cd}$ & $1.5 \mathrm{gh}$ & $4870 \mathrm{ab}$ \\
DeKalb B-660 & $68.6 \mathrm{a}$ & $109.4 \mathrm{a}$ & $80.0 \mathrm{de}$ & $2.4 \mathrm{bc}$ & $4099 \mathrm{bc}$ \\
Mayorbela & $56.2 \mathrm{f}$ & $77.5 \mathrm{e}$ & $84.8 \mathrm{a}$ & $2.1 \mathrm{cde}$ & $3886 \mathrm{bc}$ \\
PR-Mo2 $\times$ PR-3 & $57.4 \mathrm{f}$ & $77.4 \mathrm{e}$ & $80.2 \mathrm{de}$ & $2.8 \mathrm{ab}$ & $3872 \mathrm{bc}$ \\
Pioneer 304B & $66.2 \mathrm{bc}$ & $83.4 \mathrm{cde}$ & $82.2 \mathrm{~b}$ & $1.9 \mathrm{defg}$ & $3813 \mathrm{bc}$ \\
PR-Mo2 & $56.0 \mathrm{f}$ & $79.3 \mathrm{de}$ & $82.4 \mathrm{~b}$ & $2.3 \mathrm{~cd}$ & $3784 \mathrm{bc}$ \\
PR-3 & $57.0 \mathrm{f}$ & $89.4 \mathrm{bcde}$ & $78.2 \mathrm{f}$ & $2.9 \mathrm{a}$ & $2992 \mathrm{c}$ \\
X & 62.1 & 87.1 & 81.2 & 2.0 & 4598 \\
C.V., \% & 2.8 & 10.5 & 1.4 & 16.2 & 17.1 \\
\hline
\end{tabular}

${ }^{1}$ Data are means for five replicate plots. In each column, means followed by one or more letters in common do not differ significantly $(\mathrm{P}=0.05)$ according to Duncan's multiple range test.

${ }^{2}$ Rating scale: 0 (no lesions) to 4 (75 to $100 \%$ of leaf area covered with lesions).

Because plants of the third planting seemed to be less vigorous than those of the previous two plantings and showed symptoms of nematode infestation, a study was begun to obtain information about the nematodes involved. A $250-\mathrm{cm}^{3}$ soil sample was collected from the two center rows of each plot after harvest. The nematodes were extracted from the soil samples by a combination of the sieving-decanting and Baermann funnel methods (3). Nematodes were identified, and analyses of covariance and correlation were performed on total nematode counts and grain yields (third crop). 


\section{RESULTS AND DISCUSSION}

\section{FIRST CROP}

Table 1 shows means for the various characters in the 12 entries grown under the short days of the first planting.

Time to midsilk ranged from 56.0 to 68.6 days. DeKalb B-660 and DeKalb B-666 reached midsilk last (in 67.4 and 68.6 days, respectively). These times were significantly different from those of most of the other entries.

Height to the base of the lowest ear ranged from 77.4 to $109.4 \mathrm{~cm}$. The greatest ear height in DeKalb B-660 was significantly different from that in other entries except in DeKalb B-666.

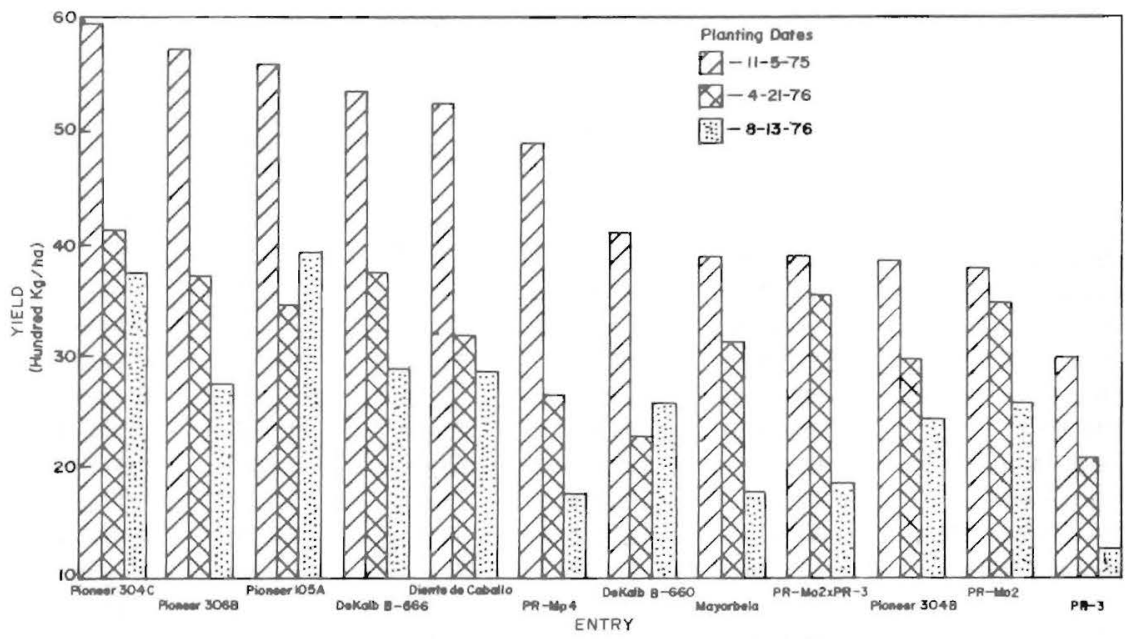

FIG. 1.-Comparison of yield in 12 corn hybrids and selections in three plantings on the same site in the same year at Isabela, P. R.

Test weight ranged from 78.2 to $84.8 \mathrm{~kg} / \mathrm{ha}$. The highest test weight, which was that in the local variety Mayorbela, was significantly different from those of the other entires. Most of the other entries had test weights of 80 to $82 \mathrm{~kg} / \mathrm{hl}$, but Diente de Caballo and PR-3 had test weights of 79.0 and $78.2 \mathrm{~kg} / \mathrm{hl}$, respectively.

Leaf blight ratings ranged from 1.4 to 2.9. The best six entries for leaf blight resistance were Pioneer 304C, PR-Mp4, Pioneer 306B, Pioneer 105A, Diente de Caballo, and Pioneer 304B, with ratings from 1.4 to 1.9 , respectively.

Yields ranged from 2992 to $5975 \mathrm{~kg} / \mathrm{ha}$ (table 1 and fig. 1). The most productive entries, in descending order, were the Pioneer hybrids 304C, 
306B, and 105A; DeKalb B-666; and Diente de Caballo. The yields of these five entries ranged from 5975 to $5223 \mathrm{~kg} / \mathrm{ha}$ and were significantly higher than those of the other entries, except PR-Mp4. The lowest producer was PR-3. Data on yields of the top five entries agree with those reported by Baynes (1), who conducted variety trials on four Caribbean Islands during 3 years, and by Chesney (2) in Guyana. In Puerto Rico, Fox et al. (7) reported yields of more than $6,000 \mathrm{~kg} / \mathrm{ha}$ from Pioneer 306B with the application of nitrogen fertilizer at $134 \mathrm{~kg} / \mathrm{ha}$.

\section{SECOND CROP}

Table 2 shows means for the various characters in the 12 entries grown under the long days of the second planting.

TABLE 2.-Yield and other characters of 12 corn entries planted on April 21, 1975, at Isabela, $P . R . '$

\begin{tabular}{|c|c|c|c|c|c|}
\hline Entry & $\begin{array}{l}\text { Time } \\
\text { to } \\
\text { midsilk }\end{array}$ & $\begin{array}{l}\text { Height } \\
\text { to } \\
\text { lowest } \\
\text { ear }\end{array}$ & $\begin{array}{c}\text { Test } \\
\text { weight }\end{array}$ & $\begin{array}{l}\text { Leaf } \\
\text { blight } \\
\text { rating }^{2}\end{array}$ & Yield \\
\hline & Days & $\mathrm{Cm}$ & $K g / h l$ & & $K g / h a$ \\
\hline Pioneer $304 \mathrm{C}$ & 57.4 de & $97.5 \mathrm{~d}$ & $72.6 \mathrm{~d}$ & $1.4 \mathrm{~b}$ & $4103 \mathrm{a}$ \\
\hline Pioneer 306B & $60.4 \mathrm{bcd}$ & $103.9 \mathrm{~cd}$ & $70.4 \mathrm{e}$ & $2.1 \mathrm{ab}$ & $3703 \mathrm{ab}$ \\
\hline Pioneer 105A & $58.0 \mathrm{cde}$ & $102.3 \mathrm{~cd}$ & $74.4 \mathrm{~cd}$ & $2.1 \mathrm{ab}$ & $3428 \mathrm{abc}$ \\
\hline DeKalb B-666 & $62.2 \mathrm{~b}$ & $120.8 \mathrm{ab}$ & $73.2 \mathrm{~cd}$ & $1.8 \mathrm{ab}$ & $3736 a b$ \\
\hline Diente de Caballo & $60.0 \mathrm{bcd}$ & $114.3 \mathrm{abc}$ & $70.2 \mathrm{e}$ & $1.7 \mathrm{ab}$ & 3180 abcd \\
\hline PR-Mp4 & $60.0 \mathrm{bcd}$ & $93.9 \mathrm{~d}$ & $70.0 \mathrm{e}$ & $1.9 \mathrm{ab}$ & 2616 cde \\
\hline DeKalb B-660 & $65.6 \mathrm{a}$ & $122.8 \mathrm{a}$ & $63.4 \mathrm{f}$ & $1.8 \mathrm{ab}$ & $2284 \mathrm{de}$ \\
\hline Mayorbela & $53.4 \mathrm{e}$ & $106.9 \mathrm{bcd}$ & $79.4 \mathrm{a}$ & $2.4 \mathrm{a}$ & 3109 bcd \\
\hline PR-Mo2 $\times$ PR-3 & $54.8 \mathrm{e}$ & $105.8 \mathrm{bcd}$ & $75.2 \mathrm{bc}$ & $2.2 \mathrm{ab}$ & $3518 \mathrm{abc}$ \\
\hline Pioneer 304B & $61.3 \mathrm{bc}$ & $99.3 \mathrm{~cd}$ & $72.3 \mathrm{de}$ & $2.1 \mathrm{ab}$ & 2961 bcde \\
\hline PR-Mo2 & $55.4 \mathrm{e}$ & $100.7 \mathrm{~cd}$ & $76.6 \mathrm{~b}$ & $1.8 \mathrm{ab}$ & $3455 \mathrm{abc}$ \\
\hline PR-3 & $60.6 \mathrm{bcd}$ & $106.9 \mathrm{bcd}$ & $70.6 \mathrm{de}$ & $2.4 \mathrm{a}$ & $2068 \mathrm{e}$ \\
\hline$\overline{\mathrm{X}}$ & 59.1 & 106.3 & 72.4 & 2.0 & 3180 \\
\hline C.V., \% & 4.1 & 10.4 & 2.1 & 25.2 & 20.6 \\
\hline
\end{tabular}

' Data are means for five replicate plots. In each column, means followed by one or more letters in common do not differ significantly $(\mathrm{P}=0.05)$ according to Duncan's multiple range test.

${ }^{2}$ Rating scale: 0 (no lesions) to 4 (75 to $100 \%$ of leaf area covered with lesions).

Time to midsilk ranged from 53.4 to 65.6 days. DeKalb B-660 and DeKalb B-666 were the last to reach midsilk, in 65.6 and 62.2 days, respectively. The time to midsilk for DeKalb B-660 was significantly different from those of other entries.

Height to the base of the lowest ear ranged from 93.9 to $122.8 \mathrm{~cm}$. The greatest ear height, in DeKalb B-660, was significantly different from those of the other entries, DeKalb B-666, Diente de Caballo, Mayorbela. 
PR-3 had the next highest ear heights. The lowest ear heights were on Pioneer 304B, Pioneer 304C, and PR-Mp4.

Test weight ranged from 63.4 to $79.4 \mathrm{~kg} / \mathrm{hl}$. The highest test weight, in Mayorbela, was significantly different from those of the remaining entries. Entries PR-Mo2 and PR-Mo2 $\times$ PR-3 ranked second and third in test weight, with 76.6 and $75.2 \mathrm{~kg} / \mathrm{hl}$, respectively.

Leaf blight ratings ranged from 1.4 to 2.4. The entries with leaf blight ratings of less than 2.0 were PR-Mp4, DeKalb B-666, DeKalb B-660, PRMo2 and Diente de Caballo. Pioneer 304C had the lowest rating (1.4) and, therefore, the best resistance to leaf blight.

Yields ranged from 2068 to $4103 \mathrm{~kg} / \mathrm{ha}$ (table 2, and fig. 1). The best producers were Pioneer 304C, DeKalb B-666, Pioneer 306B, and PR-Mo2

TABLE 3.-Yield and other characters of 12 corn entries planted on August 13, 1976, at Isabela, P. R. ${ }^{1}$

\begin{tabular}{|c|c|c|c|c|}
\hline Entry & $\begin{array}{l}\text { Time } \\
\text { to } \\
\text { midsilk }\end{array}$ & $\begin{array}{c}\text { Height } \\
\text { to } \\
\text { lowest } \\
\text { ear }\end{array}$ & $\begin{array}{c}\text { Test } \\
\text { weight }\end{array}$ & Yield \\
\hline & Days & $\mathrm{Cm}$ & $K g / h l$ & $K g / h a$ \\
\hline Pioneer $304 \mathrm{C}$ & $59.2 \mathrm{c}$ & $85.4 \mathrm{de}$ & 49.7 a & $3729 \mathrm{a}$ \\
\hline Pioneer 306B & $61.4 \mathrm{abc}$ & $104.1 \mathrm{abcd}$ & $58.3 \mathrm{a}$ & $2735 \mathrm{ab}$ \\
\hline Pioneer $105 \mathrm{~A}$ & $60.8 \mathrm{bc}$ & 90.5 cde & $55.5 \mathrm{a}$ & 3911 a \\
\hline DeKalb B-666 & $64.3 \mathrm{ab}$ & $118.4 \mathrm{a}$ & $56.7 \mathrm{a}$ & $2879 a b$ \\
\hline Diente de Caballo & $61.0 \mathrm{bc}$ & $104.8 \mathrm{abc}$ & $64.8 \mathrm{a}$ & $2848 \mathrm{ab}$ \\
\hline PR-Mp4 & $62.0 \mathrm{bc}$ & 98.5 bcde & $53.2 \mathrm{a}$ & $1752 \mathrm{~b}$ \\
\hline DeKalb B-660 & $66.2 \mathrm{a}$ & $115.0 \mathrm{ab}$ & $53.3 \mathrm{a}$ & $2584 \mathrm{ab}$ \\
\hline Mayorbela & $60.5 \mathrm{bc}$ & $83.0 \mathrm{e}$ & $57.7 \mathrm{a}$ & $1753 \mathrm{~b}$ \\
\hline $\mathrm{PR}-\mathrm{Mo} 2 \times \mathrm{PR}-3$ & $60.1 \mathrm{bc}$ & $104.3 \mathrm{abcd}$ & $52.1 \mathrm{a}$ & $1826 \mathrm{~b}$ \\
\hline Pioneer 304B & $62.3 \mathrm{abc}$ & 97.7 bcde & 56.7 a & $2402 \mathrm{ab}$ \\
\hline PR-Mo2 & $60.0 \mathrm{bc}$ & $93.6 \mathrm{cde}$ & $53.3 \mathrm{a}$ & $2576 \mathrm{ab}$ \\
\hline PR-3 & $61.5 \mathrm{bc}$ & 93.3 cde & $48.4 \mathrm{~b}$ & $1285 \mathrm{~b}$ \\
\hline$\overline{\mathrm{X}}$ & 61.6 & 99.0 & 55.0 & 2523 \\
\hline C.V., \% & 4.5 & 11.1 & 14.2 & 36.7 \\
\hline
\end{tabular}

${ }^{1}$ Data are means for five replicate plots. In each column, means followed by one or more letters in common do not differ significantly $(P=0.05)$ according to Duncan's multiple range test.

$\times$ PR-3, with yields of more than $3500 \mathrm{~kg} / \mathrm{ha}$. The four lowest producers were Pioneer 304B, PR-Mp4, DeKalb B-660, and PR-3, with yields of less than $3000 \mathrm{~kg} / \mathrm{ha}$.

\section{THIRD CROP}

Table 3 shows means for the various characters in the 12 entries in third planting.

Time to midsilk ranged from 59.2 to 66.2 days. DeKalb B-660 was the 
last to reach midsilk, a time that was significantly different from that for most of the other entries.

Heights to the base of the lowest ear ranged from 83.0 to $118.4 \mathrm{~cm}$. Ear heights for DeKalb B-666, DeKalb B-660, Diente de Caballo, PR-Mo2 $\times$ PR-3, and Pioneer 306B were greater than $104 \mathrm{~cm}$. The lowest ear heights were 85.4 and 83.0 in Pioneer $304 \mathrm{C}$ and Mayorbela, respectively.

Test weight ranged from 48.4 to $64.8 \mathrm{~kg} / \mathrm{hl}$. No significant differences in test weight were observed among entries, except that the lowest test weight, in PR-3, was significantly different from all others.

TABLE 4.-Nematodes in soil after harvest of the third crop of 12 corn entries at Isabela, P. R.

\begin{tabular}{|c|c|c|}
\hline \multirow[b]{2}{*}{ Entry } & \multicolumn{2}{|c|}{ Nematode } \\
\hline & $\begin{array}{c}\text { Pratylenchus } \\
\text { zeae }\end{array}$ & Others $^{1}$ \\
\hline & \multicolumn{2}{|c|}{ Mean no./plot ${ }^{2}$} \\
\hline Pioneer $304 \mathrm{C}$ & 480 & 96 \\
\hline Pioneer $306 \mathrm{~B}$ & 592 & 16 \\
\hline Pioneer 105A & 832 & 112 \\
\hline DeKalb B-666 & 740 & 128 \\
\hline Diente de Caballo & 816 & 32 \\
\hline PR-Mp4 & 528 & 80 \\
\hline DeKalb B-660 & 480 & 128 \\
\hline Mayorbela & 800 & 80 \\
\hline PR-Mo $2 \times$ PR- 3 & 1232 & 48 \\
\hline Pioneer 304B & 384 & 80 \\
\hline PR-Mo2 & 736 & 96 \\
\hline PR-3 & 1040 & 80 \\
\hline
\end{tabular}

' Helicotylenchus spp., Tylenchus spp., Aphelenchus spp., and Xiphinema spp.

${ }^{2}$ Based on a $250-\mathrm{cm}^{3}$ soil sample from five replicate plots for each entry.

Yields ranged from 1285 to $3911 \mathrm{~kg} / \mathrm{ha}$. Pioneer hybrids $105 \mathrm{~A}$ and $304 \mathrm{C}$ were the top producers, with yields of 3911 and $3729 \mathrm{~kg} / \mathrm{ha}$, respectively. The four lowest producers were (in descending order), PR-Mo2 $\times$ PR-3, Mayorbela, PR-Mp4, and PR-3, with yields of less than $2000 \mathrm{~kg} / \mathrm{ha}$.

Table 4 shows the mean number of nematodes per plot after harvest of the third crop. The most abundant nematodes found in the soil rhizosphere were Pratylenchus zeae and species of Helicotylenchus, Tylenchus, Aphelenchus, and Xiphinema. Analyses of covariance and correlation of yield and numbers of nematodes identified no significant relationships. However, nematode counts after harvest of the third crop may not have been sufficient to reveal such a relationship; data on the prevalence of nematodes before each of the three plantings might have been more informative. 
No reports are available in Puerto Rico on the effect of soil nematodes on corn, but there are many reports of studies conducted elsewhere. Edmunds et al. (6) cited various studies indicating that Pratylenchus spp. seem to be the most prevalent nematodes associated with corn. Young (12) reported that the most abundant nematodes that severely damaged roots of field corn in Texas were Trichodurus christiei, $P$. brachyurus, $P$. zeae, Xiphinema americanum, and species of Criconemoides and Belonolaimus. Johnson (9) concluded that plant parasitic nematodes, especially Criconemoides ornatus, species of Helicotylenchus, and T. christiei, were mainly responsible for reduced yields of sweet corn in Georgia.

Hernández-Catalán (8) evaluated 10 grain sorghum (Sorghum bicolor (L.) Moench) lines on the same site where the three corn crops were established in the present study. He found that the average grain yield for the 10 lines was about $3095 \mathrm{~kg} / \mathrm{ha}$ when the soil was treated with fensulfothion $(O, O$-dimethyl $O$-[ $p$-(methylsulfinyl)phenyl $]$ phosphorothioate) at $33.7 \mathrm{~kg}$ of active ingredient per hectare, but was only $2650 \mathrm{~kg} /$ ha when the soil was not treated. The soil contained an average of 481 Pratylenchus spp. per $250 \mathrm{~cm}^{3}$ before treatment but only 18 per $250 \mathrm{~cm}^{3}$ at harvest after treatment (8).

\section{COMPARISON OF THE THREE CROPS}

Mean periods to midsilk were similar in crops 1 and 3, 62.1 and 61.6 days, respectively, but only 59.1 days in crop 2 (tables 1-3). The coefficients of variation (C.V.'s) for the time to midsilk were low, from 2.8 to $4.5 \%$, in all three crops.

As judged from mean height to the base of the lowest ear, plants in crop 1 (April planting) were taller than those in crops 1 (November planting) and 3 (August planting). Mean ear heights were 106.3, 87.1, and $99.0 \mathrm{~cm}$, respectively (tables 1-3). The C.V.'s for ear height in the three crops were very similar, about $11 \%$.

The mean test weight decreased from 81.2 to 72.4 to $55.0 \mathrm{~kg} / \mathrm{hl}$ in crops, 1,2 , and 3 , respectively (tables $1-3$ ). The CV for test weight was only $1.4 \%$ in crop 1 and $2.1 \%$ in crop 2, but increased to $14.2 \%$ in crop 3.

The mean leaf blight rating was 2.0 in both crop 1 and crop 2 (tables 1 and 2). The CV was $16.2 \%$ in crop 1 and $25.2 \%$ in crop 2.

The mean grain yield for the 12 entries decreased to 4598, to 3180 , to $2523 \mathrm{~kg} / \mathrm{ha}$ in crops 1, 2, and 3, respectively (tables 1-3). The respective C.V.'s for the crops were 17.1, 20.6, and $36.7 \%$. The highest yield had been expected in crop 2, when the entries were grown under long days (April planting), rather than in crop 1.

The analysis of variance for the three harvests combined showed that three Pioneer hybrids (304C, 105A, and 306B) and DeKalb B-666 were 
the top grain producers, with yields ranging from 12,000 to $14,000 \mathrm{~kg} / \mathrm{ha}$ / year. Differences in yield among these four entries were not statistically significant.

Diente de Caballo was the fifth best producer, and it was followed by PR-Mo2, PR-Mo2 × PR-3, and Mayorbela; the grain yields in these four entries ranged from 9,418 to $11,307 \mathrm{~kg} / \mathrm{ha}$ /year. Entries PR-Mp4, Pioneer 304B, and DeKalb B-660 were next, with yields ranging from 9,024 to $9,294 \mathrm{~kg} / \mathrm{ha} /$ year. The yield of $6,468 \mathrm{~kg} / \mathrm{ha} /$ year in PR-3 was significantly lower than those in the other entries.

Besides showing the potentials of hybrids, population samples, and local corn varieties, this study demonstrated that three corn crops on the same site in the same year can produce grain yields of more than 13,000 $\mathrm{kg} / \mathrm{ha} /$ year. Diente de Caballo produced more than $11,000 \mathrm{~kg} / \mathrm{ha} /$ year, a yield that compares favorably with that of a well-adapted hybrid such as Pioneer 304C.

\section{RESUMEN}

Doce selecciones de maíz (híbridos y selecciones) se sembraron en el mismo lugar durante las siguientes fechas: 5 de noviembre de 1975 (cosecha 1); 21 de abril de 1976 (cosecha 2) y 13 de agosto de 1976 (cosecha 3). Los experimentos se llevaron a cabo en la finca experimental de Isabela del Instituto Mayagüezano de Agricultura Tropical del Departamento de Agricultura de los Estados Unidos. Las 12 selecciones de maiz fueron las siguientes: híbridos Pioneer 304C, 306B, 105A; DeKalb B-660 y B-666; selecciones de PR-Mp4, PRMo2, PR-3, PR-Mo2 × PR-3, y las variedades nativas Diente de Caballo y Mayorbela. Se utilizó un diseño de bloques al azar con cinco repeticiones.

Los resultados indican que: 1) los días transcurridos desde la siembra a la mitad de la floración fueron similares para las cosechas 1 y 3 , pero las plantas fueron más precoces en la cosecha $2 ; 2$ ) el peso prueba $(\mathrm{kg} / \mathrm{hl})$ medio descendió de la cosecha 1 a la $3 ; 3$ ) la infección causada por Bipolaris maydis fue, en promedio, similar en las cosechas 1 y 2 ; 4) el mejor productor en las tres cosechas fue Pioneer 305C con 5975,4103 y $3729 \mathrm{~kg} / \mathrm{ha}$, respectivamente. La producción media de las 12 selecciones fue de 4598, 3180 y $2523 \mathrm{~kg} / \mathrm{ha}$ para las cosechas 1,2 y 3 , respectivamente; 5 ) el nematodo principal, al finalizar la tercera cosecha, fue Pratylenchus zeae; 6) el híbrido Pioneer 304C, el mejor productor en las tres cosechas, arrojó el segundo número menor de nematodos por $250 \mathrm{~cm}^{3}$ de suelo; 7) la seleccion PR-3 y el híbrido PR-Mo2 $\times$ PR-3 arrojaron la infestación más alta de nematodos con 1040 y 1232 por $\mathrm{cm}^{3}$ de suelo; 8) existe una buena posibilidad de que la pobre producci ón que se observó en las cosechas 2 y 3 pueda atribuirse a la infección de nematodos antes mencionada.

Este estudio demostró, además, que es posible lograr tres cosechas de maíz en el mismo lugar con producciones sobre $13,000 \mathrm{~kg} / \mathrm{ha}$. La variedad nativa Diente de Caballo fue una de las cinco mejores productoras al totalizar las tres cosechas, con 11,307 kg/ha.

\section{LITERATURE CITED}

1. Baynes, R. A., 1972. Yields of maize (Zea mays L.) in four Caribbean islands as influenced by variety and plant density, Trop. Agri. (Trinidad) 49: 37-51.

2. Chesney, H. A., 1969. Effect of fertilizer nitrogen, phosphorus, and potassium on yield of corn, Zea mays var. "Pioneer-306", Carib. Food Crops Soc. 7: 334-338.

3. Christie, J. R. and Perry, V. G., 1951. Removing nematodes from soil, Proc. Helminthol. Soc. Wash. 18: 106-108.

4. Craig, J., Scott, G. E., Sprague, G. F., and Wester, O. J., 1976. Registration of PR-Mp1 and PR-Mp4 maize germplasm, Crop Sci. 16: 746.

5. — Webster, O. J., and Zuber, M. S., 1976. Registration of PR-Mo2 maize germplasm, Crop Sci. 16: 446-447. 
6. Edmunds, J. E., Boothroyd, C. W., and Mai, W. F., 1967. Soil fumigation with D-D for control of Pratylenchus penetrans in corn, Plant Dis. Rep. 51: 15-19.

7. Fox, R. H., Talleyrand, H., and Bouldin, D. R., 1974. Nitrogen fertilization of corn and sorghum grown in Oxisols and Ultisols in Puerto Rico, Agron. J. 66: 534-40.

8. Herńandez-Catalán, O. V., 1977. Nematodos del sorgo (Sorghum bicolor (L.) Moench) en Puerto Rico: Patogenicidad y combate, MS Thesis, Mayagüez Campus, University of Puerto Rico, Mayagüez, P. R.

9. Johnson, A. W., 1975. Resistance of sweet corn cultivars to plant-parasitic nematodes, Plant Dis. Rep. 59: 373-376.

10. Talleyrand, H., Fox, R. H., and Lugo-López, M. A., 1976. Nitrogen fertilization of a high yielding white kernel corn in Oxisols and in Ultisols in Puerto Rico, J. Agri. Univ. P. R. 60(3): 336-343.

11. Webster, O. J. and Walker, D. W., 1977. A field test of corn cultivars for insect and disease resistance, J. Agri. Univ. P. R. 61(3): 319-325.

12. Young, P. A., 1964. Control of corn nematodes with Vorlex and D-D, Plant Dis. Rep. 48: $122-123$. 